\title{
Paths of Glory: Injustice and Crime against Humanity
}

\author{
Shampa Iftakhar
}

\begin{abstract}
Based on a real-life experience of the World War I, Humphrey Cobb wrote Paths of Glory in 1935.This novel has a strong voice against inhumanity and injustice. Stanley Kubrick took the same plot for the movie Paths of Glory. Both the novel and the film are the anti-war statements that assert the crime against humanity when justice is denied for power and greed. Some countries of this modern world have experienced injustice and crime against humanity. Now we see blood shedding, brutal planned murder and, injustice in Gaza. This paper intends to analyze how Paths of Glory, both novel and film, successfully forecast greedy human nature that is responsible for the crime against humanity and injustice which has been repeated over a period of time and how two are allegorical representation of our present world.
\end{abstract}

Index Terms-Crime against humanity, injustice, human nature, allegorical representation.

\section{INTRODUCTION}

The ultimate results of a war are crime against humanity, injustice, genocide, destruction of moral codes, and rise of new nation with new social orders. David Matas states, "World War I saw the Armenian massacre - the Turkish murder of hundreds of thousands of Armenian men, women and children and the attempt to exterminate all Armenians within the boundaries of the Ottoman empire" [1]. He views that this sort of massacre was repeated in World War II as crimes against humanity were not prosecuted [1]. Humphrey Cobb's Paths of Glory which was published in 1935 and Stanley Kubrick's movie version of Paths of Glory which was released in 1955, dealt with injustice and crime against humanity. The world observes injustice and crime against humanity in Gaza in 2014. We experience how greed degenerates human nature; how greedy men ignore the plea of humanity.

\section{PATHS OF GLORY: NOVEL AND MOVIE}

In the book review, David Simon comments that Paths of Glory is Cobb's careful representations of the state of humanity, the use of institutionalized terror and the savagery of modern war [2]. Cobb served in the Canadian Army during the First World War and wrote this novel as an anti-war statement. In the novel soldiers know that they must obey the command of officers; some proud army officers who are acting solely for self-interest, for the promotion, for own ego regardless to the lives of the men who meet death mercilessly. The common soldiers follow the paths of glory knowing that

Manuscript received April 5, 2015; revised September 10, 2015.

Shampa Iftakhar is with Daffodil International University, Bangladesh (e-mail: shampa.eng@daffodilvarsity.edu.bd). this glory will bring them death and reward to the heartless officers. Here lies the irony of glory.

In the novel, we see that French General Assolant has given order to assault and take a German position called as The Pimple. Assolant claims that the Pimple is the "key position" that must be "captured - and held". Assolant calls the 181st regiment. This regiment is supposed to be on leave. Army Commander argues that this desire is "absurd' as the soldiers are "absolutely exhausted" [3]. He is aware of Assolant's greedy nature and out of contempt he utters. "What vulgarity! What a bounder! But he'll take the Pimple" [3]. Colonel Dax of the 181st Regiment of the line, "next on the General's stars and promotion in the Legion of Honour" [3] doubts rightly it is impossible and he only thinks of "compact mass of living human, vulnerable flesh" [3].

As the story proceeds, we see that a patrol is sent, where one of the men, named Lejeune, accidently gets killed the drunken commander Roget. The next morning the attack on the Pimple is launched. It becomes impossible to take position on the Pimple as in the 181st regiments, the soldiers are extremely tired and some soldiers are fresh and new. Everything goes wrong. A heavy rain falls just as the French troops are to go over the top and begin their attack across no man's land. The German artillery and machine gun fire is so effective that the assault fails miserably to move advance. Some troops never even get out of their trenches. Assolant, a heartless and crazy General, wants to be rewarded by medals and glory for being able to take The Pimple. But when everyone else has failed to do so he becomes angry and seeks retribution from the regiment involved. He orally orders the battery commander to fire on the men. "General orders both batteries to fire on 32, 58 and 73" [3].

But Pelltier, battery commander, is presented as a sensible man, and he replies, "With due respect, sir, no. Unless it is in writing, and signed by you" [3]. He also adds Assolant has "no right to shot down" [3] his men unless he is "willing to take full and undivided responsibility for it" [3]. At this point, Assolant orders a court marital to protect his dignity at the cost of others as mentioned in the novel "to give others a lesson in obedience and duty" [3]. Three men are selected randomly and sent to the court-martial (better we can use the word kangaroo-court) where justice is denied. Only Captain Etienne voices for justice and demands to keep stenographic notes. He adds, "I protest against the fact that no stenographic notes of the trial were kept. This deprives the accused of an instrument with which to back up an appeal for pardon to the President of the Republic" [3]. He declares the accused as "heroes" [3].

But intentionally the court does not keep the notes and argues that "presidential pardon exists no longer" [3] as "the president relinquished his prerogative of pardon" [3]. The 
president of the council says that the men are on trial for current "cowardice in the face of enemy" [3], not their former bravery. Their previous medals are no defense. Here Paths of Glory has its focus on chain of command. David Simon claims that the target is army itself as an institution, an unwieldy and unyielding organism that lurches from one murderous horror to the next, guided only by whichever combination of ambitions and vanities are in play at any moment [2].

The court martial is a sham with the verdict and sentence already decided ahead of time. The three men are tied to posts and shot the next morning in front of the entire regiment as examples for all the survivors that we can term as the most inhuman act on the part of institution.

Jesse Bier comments that this movie is "thematically centered and dramatically decisive than the book" [4]. Paths of Glory is a masterful, unsentimental, classic anti-war film about World War I. Here we get a hero. Kirk Douglas performed the Colonel Dax who feels a lot for tired soldiers and tried to defend them. The story of the movie as same as we get in the novel. The suicidal attack on an impregnable fortress named "Ant Hill" in the film. They fail to take a position on "Ant Hill". The film presents a raw, controversially-offensive and critical assessment of hypocritical French military and bureaucratic authorities who callously condemn and sacrifice three randomly-chosen innocent men with execution (for cowardice) for their own fatal blunder. These are "nuances upon nuances"[3]. Kubrick has bought the "gamesmanship of ambition and command"[3] to a great height that we feel hatred for their injustice.

At first Mireau, (in novel General Assolant) demands a court-martial for the whole regiment, calling for ten or twelve victims from each company [4]. Colonel Dax is a clean and sympathetic man. He, like Cobb's colonel, offers Mireau to punish him( Dax) since he was in charge of the whole infantry regiment. Dax's offer is a reflection on General Mireau because he was even more in charge of the whole attack.

The injustice again comes forward when Dax meets General Brouillard. General Brouillard is presented as a "dispassionate cynic" [4] who is "arguing cold-bloodedly" that execution is good for morale. "If troops are not like animals, they are at least like children who should be seen in action and never heard in protest. In any case they need discipline and are better for it in the long run" [4]. When Dax exposes Mireau's stupid artillery order, he feels grateful and offers Dax Mireau's job as a reward for his ( Dax) intelligence and "frank power play" [4]. This offer surprises him. General is also surprised by Dax's responsive slurs on his unmitigated subjectivity and degeneracy. General regrets that this reaction is "pitiable idealism" [4]. Dialogues between General Broulard and Colonel Dax prove this.

General Brouillard: Colonel Dax, you're a disappointment to me. You've spoiled the keenness of your mind by wallowing in sentimentality. You really did want to save those men, and you were not angling for Mireau's command. You are an idealist... and I pity you as I would the village idiot. We're fighting a war, Dax, a war that we've got to win. Those men didn't fight, so they were shot. You bring charges against General Mireau, so I insist that he answer them. Wherein have I done wrong?

Colonel Dax: Because you don't know the answer to that question. I'll pity you.

His defense to safe his soldiers, makes him a sensible and moral human being. He protests the whole proceeding of court-martial. His defense is fearless to establish human rights. He objects the lack of stenographic record, as "a mockery of justice" [4].

We see how modern war has got marked for "vast number of causalities and horrors" [3]. Common soldiers become the target of these causalities and horrors. Common soldiers who "was ripped out of his normal civilian life to be made cannon fodder for the killing machines in the hands of the general and political leader" [3]. These soldiers come from "country's heartland" and "respond to their nations call" [3] leaving behind their wife, children and relatives. But at the end they meet "the inherent injustice" [3]. As it is mentioned in the Introduction of the novel:

On a basic level, the common man was often led to death by men he barely knew. As large armies and organizations grew in number, it becomes increasingly impossible for the man of the top to know the common man or to known by him as well, and as a consequence, life or-death decisions were made by those who had little or no direct human contact [3].

Mireau in the Movie or Assolant in the novel represents dehumanized world. Injustice is the ultimate consequence of this dehumanized world. Assolant is detached from the common soldiers "who are continually asked to do more much, much more than humanly possible by generals who are detached by their own humanity" [3]. As in the movie, we see an unnamed tired soldier dreams of sweet home rather than to kill another man in the battle field. But Mireau scolds in a harsh voice as he hardly exercises his human faculty. He is more for rank; he is more for power. But he does not know how to manage a war. His ignorance results into injustice that brings death sentences to three innocent soldiers. This punishment "forms the basis of the novel injustice" [3].

We see the same thing in Stanley Kubrick's movie version of Paths of Glory. As Roger Ebert, a famous movie reviewer, comments that we have seen harrowing battlefield carnage, a morally rotten court-martial, French army generals corrupt and cynical beyond all imagination [5]. This movie was not a big hit. But the movie forecasts a strong voice against crime against humanity and injustice.

\section{INJUSTICE AND CRIME AGAINST HUMANITY: GAZA IN} 2014

Justice and humanity are closely related. John Rawls views "justice as fairness" [6] and David Luban claims that humanity means quality to being human and the aggressions of all human beings i.e. mankind [7]. When we discard humanity, injustice happens. This term "crime against humanity" is first used in Nuremberg charter that denotes crime against humanity offends against humanity where human values are violated by crimes [8]. In Hannah Arendt words "crime against the human status or against the very 
nature of mankind" [9]. Xunwu Chen mentions that in normative justice, the value of humanity has priority over other values. Here justice rejects all sorts of violence and demands equal respect for all human beings [10].

But injustice rules the world. So we visualize the brutal murder and violence in Gaza. Killing in the Gaza streets can be termed as a parallel story of WWI and WWII. This killing is planned and is "carried out savage enthusiasm by Israel's "citizen army" [11]. James Petras in his online report titled reports that the world sees except "organized supporters in the major Zionist organization" [11], how Israel is trying to invade Gaza. Israel has launched its "systematic attack on the civilians and basic infrastructure" [11]. This planned killing and violence are against justice. This is definitely crime against humanity. Politicians and leaders of the present world hardly come out of their greedy natures. So in a large scale, humanity has been violated as David Simon in the book review of Paths of Glory mentions:

The senselessness of the action, coupled with the callow ambitions of those in command, is indeed ripe with portent for the century ahead - an epoch in which barbarity would fall as much on the civilian occupants of a Warsaw, a Dresden, or a Nagasaki as upon armed combatants.

As the generals bicker over the number to be shot in order to cover their own failure, we can already hear the cold calculations a century hence, the arithmetic of terror that is in play every time a suicide bomber steps onto a Tel Aviv bus, or, for that matter every time a helicopter fires a missile into a crowded Gaza street [2].

Very unfortunately, the international community has failed to hold the Israeli state countable for war crimes, violation of international laws [12]. Ajamu Baraka expresses that human rights organizations and United States have failed to bring Israel to justice. But these organizations and United Nations special procedures have produced details reports on crime against humanity caused by Israel over the last four decades [12]. But these never work to stop injustice and crime in Gaza. The voice of the West is also very hypocritical. As Richard Falk in his interview with Aljazeera remarks:

With cynical disregard of the realities of the latest confrontation between Israel and Palestine, instead of condemning such recourse to massive violence as "aggression" that violates the UN Charter and fundamental international law principles, the reaction of western diplomats and mainstream media has perversely sided with Israel. From the UN Secretary-General to the president of the United States, the main insistence has been that Hamas must stop all rocket attacks while Israel is requested ever so politely to show "maximum restraint" [13].

In Cobb's Paths of Glory, a human being are presented as a 'worthless' [2]. Army as an institution is the ultimate target both in film and movie as this institute is empowered with highest power during war time. Gaza's condition can be viewed in term of institutional unchecked power. Unchecked power is dangerous. John Kenneth Galbraith expresses his awareness about the negative influence of unchecked power [14].

\section{CONCLUSION}

Paths of Glory is the modern allegory to depict the present condition of Gaza where three accused soldiers allegorically symbolize the civilians and children of Gaza who become ultimate brutal target of missiles. To a large scale Israeli Prime Minister Benyamin Netanyahu and his Cabinet, leading Party and Knesset are represented as General Assolant (who is called as General Insolent by his soldiers) of the novel or General Brouillard of the movie. Along with his all followers General Brouillard, stands for those blind and proud Israeli Jews who march with banners and chant demanding "Death to Arabs" [11]. General Brouillard allegorically represents these Jews. In the movie version we see him asking some unnamed soldiers "Are you ready to kill more Germans?" So tragedy of humanity continues even after a century.

So as the movie and novel depict, three lieutenants are sentenced to death for "cowardice" and Palestinian dies for as Israel rejects humanitarian ceasefire. Thus Israel has committed grave crime against humanity, according to the Geneva Conventions and the legal standards established at Nuremberg. According to Nuremberg Charter, in paragraph 6 (c) Crimes Against Humanity is defined as "murder, extermination, enslavement, deportation, and other inhumane acts committed against any civilian population, before or during the war, or persecutions on political, racial or religious grounds in execution of or in connection with any crime within the jurisdiction of the Tribunal, whether or not in violation of the domestic law of the country where perpetrated" [8].

Gaza has been inflicted with murder and so many inhumane acts. The saga of pathetic death has been re-rehearsed in World War I and World War II and again in 2014. No one can escape from the brutality. Paths of glory lead to death and crime of humanity.

\section{REFERENCES}

[1] D. Matas, "Prosecuting crimes against humanity: The lessons of World War I," Fordham International Law Journal, vol. 13, no. 1, pp. 86-104, 1989.

[2] D. Simon. (April 2012). Introduction: Paths of glory by Humphrey Cobb. [Online]. Available: http://www.davidsimon.com/forward-paths-glory-by-humphrey-cobb

[3] H. Cobb, Paths of Glory, New York: Viking Press, 1935.

[4] J. Bier. (1985). Cobb and Kubrick: Author and auteur: Paths of glory as novel and film. National Journal of Literature and Discussion. [Online]. 16(3). p. 65. Available: http://www.vqronline.org/./cobband kubrick-authour_and_auteur

[5] R. Ebert. (February 2005). Reviews great movie paths of glory. [Online]. Available: http://www.rogerebert.com/reviews/great-moviepaths- of-glory-1957

[6] J. Rawls, A Theory of Justice, Cambridge, MA: Harvard University Press, 1971, p. 17.

[7] D. Luban, "A theory of crimes against humanity," Yale Journal of International Law, vol. 29, p. 87, 2004.

[8] R. H. Jackson, R. Falco, and L. Nikitchenko, "The charter and judgment of the Nürnberg Tribunal - History and analysis," United Nations- General Assembly, USA: New York, pp. 65-66, 1949.

[9] H. Arendt, Eichmann in Jerusalem: A Report on the Banality of Evil, London: Penguin, 1963, pp. 267-268.

[10] X. Chen, Justice, Humanity and Social Toleration, USA: Rowland and Littlefield Publishers, 2008, pp. 68-88.

[11] J. Petras. (August 2014). Total war against Gaza and Israeli Genocide-its willing accomplices. Global Research. [Online]. Available: http://www.Globalresearch.com/total-war-against--gazaisraeli-genocide-and-its-wi 
[12] A. Baraka. (July 2014). Witness to an international crime: Israeli state in terrorism in Gaza. [Online]. Available: http://www.blackagendareport.com.>Blogs>Ajumabaraka's blog

[13] R. Falk. (July 2014). Tormenting Gaza-Aljazeera English. [Online]. Available: http://www.aljazeera .com/07/tormenting- gaza

[14] J. K. Galbraith, American Capitalism: The Concept of Countervailing Power, Boston: Houghton Mifflin, ch. 3, 1952.

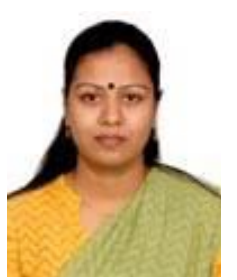

Shampa Iftakhar is an assistant professor at the Department of English, Daffodil International University. She was born in Bangladesh on January 1, 1979. She has obtained her B.A. (Hons) degree and MA degree in English literature from Jahangirnagar University, Bangladesh. She has been teaching for eleven years. She started her career as a teacher of Oxford International School, Dhaka. Then she joined in Stamford University Bangladesh. From 2004 to 2015, she has been teaching different courses such as English fundamentals, history of English literature, composition, advanced reading and writing, public speaking, and $18^{\text {th }}$ century literature and Victorian poetry. She joined in Daffodil International University in May 2013. Here she is conducting classes on history of English literature, $17^{\text {th }}$ century literature, and American literature: novel and drama, English I and English II. She has got some of her papers published in different journals. Some of her recent publications include "Rethinking English teaching through CLT in government primary schools of Bangladesh," DIU Journal of Humanities and Social Science, volume 2, July 2014; "Mobile language choice in SMS, M-learning and MALL," Outlooks VUB Studies in Language, Literature and Culture, Journal of Department of English, Victoria University Bangladesh, 2nd issue, October 2014.

She has presented papers in some international conferences. She is a life time member of BELTA and NELTA. Her recent research areas include technology in education, teacher education, American literature, history, film and literature, and ELT. 